\title{
Toxicological analysis of the risk of lead exposure in metal processing
}

\author{
Ivan M Krstić ${ }^{\text {, Vesna B Lazarević }}{ }^{2}$, Goran L Janaćković ${ }^{1}$, Nenad S Krstić ${ }^{3^{*}}$, \\ Nemanja Anastasijević ${ }^{3}$, Dragan M Djordjevićc ${ }^{3}$, Dejan Dulanović ${ }^{3}$ \\ ${ }^{1}$ Faculty of Occupational Safety, University of Niš, Čarnojevića 10a, ${ }^{2}$ Centre for Preventive Medical Care, Military Hospital, \\ Bulevar dr Zorana Djindjića bb, ${ }^{3}$ Department of Chemistry, Faculty of Sciences and Mathematics, University of Niš, Višegradska \\ 33, 18000 Niš, Serbia
}

${ }^{*}$ For correspondence: Email: nenad.krstic84@yahoo.com; Tel: +381 18533015

Sent for review: 13 July 2017

Revised accepted: 20 November 2017

\begin{abstract}
Purpose: To evaluate toxicological risks for workers who are exposed to lead in their work environment. Methods: Since it is an important indicator of toxicological risk, a statistical analysis of lead concentration and biological lead toxicity markers in blood and urine were performed for both exposed and control groups. Both experimental groups consisted of employees from "NISSAL" JSC factory. Analytical epidemiological method in the form of a retrospective cohort study was applied, and covered the period from 2001 to 2010. The concentration of lead, $\delta$-aminolevulinic acid, and coproporphyrin in biological samples were determined by spectrophotometric methods.

Results: The results showed a high positive correlation between lead concentrations in blood and urine and the length of exposure of the participants $(p<0.01)$. Also, increase of lead concentration in the biological material significantly increased $\delta$-aminolevulinic acid $(p<0.01)$ and slightly increased the concentration of coproporphyrin, both of which are important indicators of toxicological risk.

Conclusion: The control group of employees belonged to the normal risk category, while the exposed group belonged to a moderate risk category. Correlation between the monitored parameters is statistically significant at $p<0.01$ and $p<0.05$.
\end{abstract}

Keywords: Lead, $\delta$-Aminolevulinic acid, Coproporphyrin, Chronic exposure, Toxicity, Correlation

\begin{abstract}
This is an Open Access article that uses a funding model which does not charge readers or their institutions for access and distributed under the terms of the Creative Commons Attribution License (http://creativecommons.org/licenses/by/4.0) and the Budapest Open Access Initiative (http://www.budapestopenaccessinitiative.org/read), which permit unrestricted use, distribution, and reproduction in any medium, provided the original work is properly credited.
\end{abstract}

Tropical Journal of Pharmaceutical Research is indexed by Science Citation Index (SciSearch), Scopus, International Pharmaceutical Abstract, Chemical Abstracts, Embase, Index Copernicus, EBSCO, African Index Medicus, JournalSeek, Journal Citation Reports/Science Edition, Directory of Open Access Journals (DOAJ), African Journal Online, Bioline International, Open-J-Gate and Pharmacy Abstracts

\section{INTRODUCTION}

Lead as a highly toxic, non-essential metal with a cumulative effect in humans, represents a serious environmental and health issue. People can experience lead poisoning from various sources: contaminated air, food, water, work environment, etc [1]. After entering the human body, lead is transported through the blood system to the target organs (liver, kidneys, brain, or bones) where it manifests its toxic effects due to its high affinity for binding with donor atoms of functional groups from different biomolecules (enzymes) [2]. Lead values in the blood are the 
most common bioindicator of direct exposure to this toxic metal, which causes significant disorders in blood parameters [3,4]. After interacting with enzymes, lead inhibits their activity, and due to this inhibition, the values of $\delta$ aminolevulinic acid (synthetase and dehydratase), coproporphyrin, and protoporphyrin in erythrocytes, plasma and urine are increased [5]. Lead is eliminated from the body mostly through the urinary system, and partly through the gastrointestinal tract [6].

According to the American Center for Disease Control (ACDC) [7], blood lead level of less than $0.98 \mu \mathrm{mol} / \mathrm{dm}^{3}$ ( $\mu \mathrm{M}$ further in the manuscript) is considered normal, 1.21 to $2.37 \mu \mathrm{M}$ belongs to the moderate risk category, 2.41 to $3.33 \mu \mathrm{M}$ to the high-risk category, while the amounts higher than $3.38 \mu \mathrm{M}$ fall into the urgent risk category. Nevertheless, the prolonged exposure to lowlevel toxicity $(<1.16 \mu \mathrm{M})$ can lead to various psychological disorders and learning disabilities among children. Naturally, these symptoms can occur among children even in the case of lead intake in amounts less than $0.24 \mu \mathrm{M}$. The allowed blood lead levels in some industrialized countries are shown in Table 1.

Table 1: Blood lead levels in some industrialized countries

\begin{tabular}{lcc}
\hline Country & $\begin{array}{c}\text { Concentration } \\
(\mu \mathbf{M})\end{array}$ & Ref \\
\hline Sweden & 0.12 & \\
USA & 0.13 & {$[8]$} \\
Poland & 0.13 & \\
Thailand & 0.15 & {$[9]$} \\
Germany & 0.17 & {$[10]$} \\
Italy & 0.22 & {$[11]$} \\
United Kingdom & 1.45 & {$[12]$} \\
Australia & 2.41 & \\
\hline
\end{tabular}

The aim of the present study is to evaluate toxicological risks for the workers who are exposed to lead in their work environment (NISSAL factory, Niš, Serbia; hereinafter "Nissal"). The values of this toxic metal and the biological markers ( $\delta$-aminolevulinic acid and coproporphyrin) in the blood and urine were recorded and monitored.

\section{EXPERIMENTAL}

The study was carried out by monitoring the values of lead and biological markers in the blood and urine in groups of employees (the exposed and the control group) in "Nissal", in the period from 2001 to 2010. All the employees in the exposed group (871 individuals) were male, with the average age of 45.4 , and all of them had been employed at least one year in the metal processing industry. The employees in the control group (60 individuals) were also exclusively male, with the average age of 44.1 , and all of them were office employees, protected from lead exposure.

Analyses were made according the approvals at the Institute of Employees Health Care, Niš (no. 01-01/2011); Institute of Public Health, Niš (no. 9-25/2011); and Military Medical Academy in Belgrade (no. 3473-1/2010), all of this in accordance with international guidelines for animal/human studies [13]. Lead level values in the examined biological samples were determined by Atomic Absorption Spectrometry (AAS) and Graphite Furnace Atomic Absorption Spectrometry (GFAAS). Coproporphyrin (CP) and $\delta$-aminolevulinic $(\delta-A L A)$ acid values were determined by UV-VIS spectrophotometry (Varian Cary-USA 50) [13-15].

\section{Statistical analysis}

All results are presented as average values of all samples from each group (mean \pm standard deviation), and statistics evaluated by Students' t-test (independent sample), linear regression, and correlation analysis. Statistical significance was set at $p<0.01$ and $p<0.05$.

\section{RESULTS}

The values of the investigated parameters for both the exposed and the control group of employees which include results of tests of lead levels in the blood and urine, as well as coproporphyrin and $\delta$-aminolevulinic acid concentrations in the urine, are shown in Figure 1.

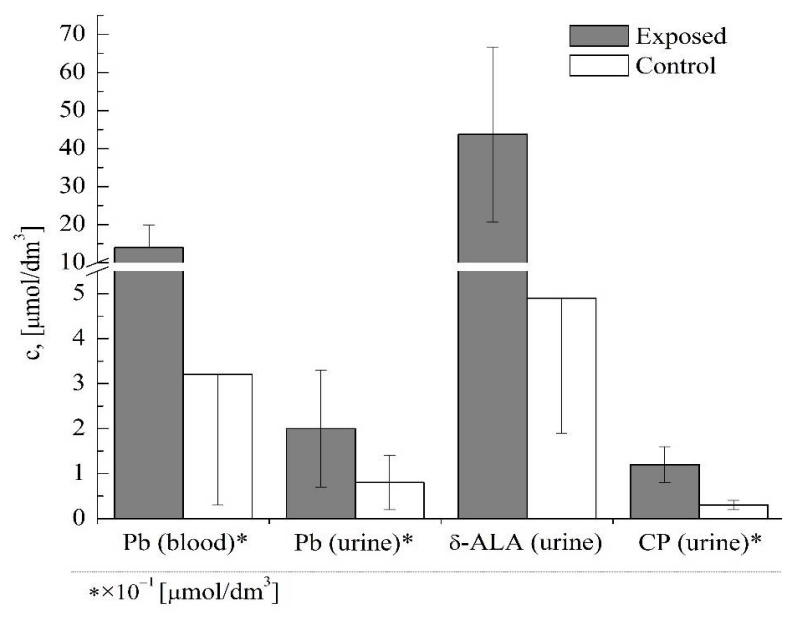

Figure 1: Levels of $\mathrm{Pb}$ in blood and urine, and $\delta$-ALA and $\mathrm{CP}$ levels in urine 
(a)

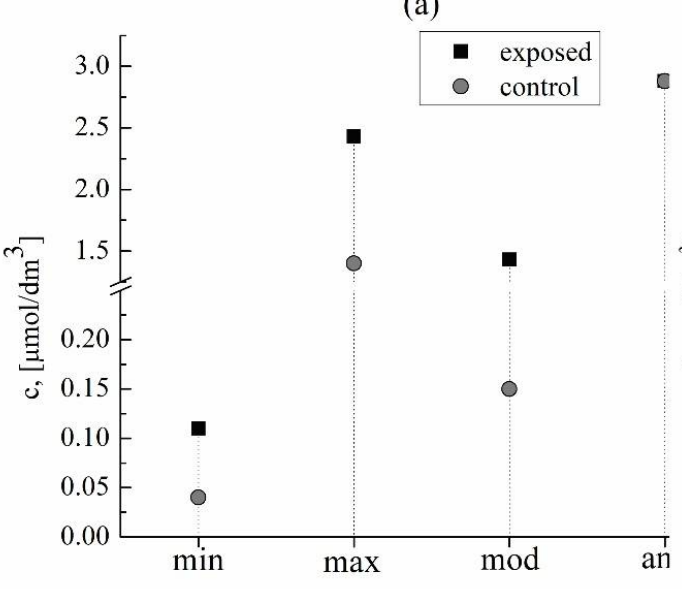

(c)

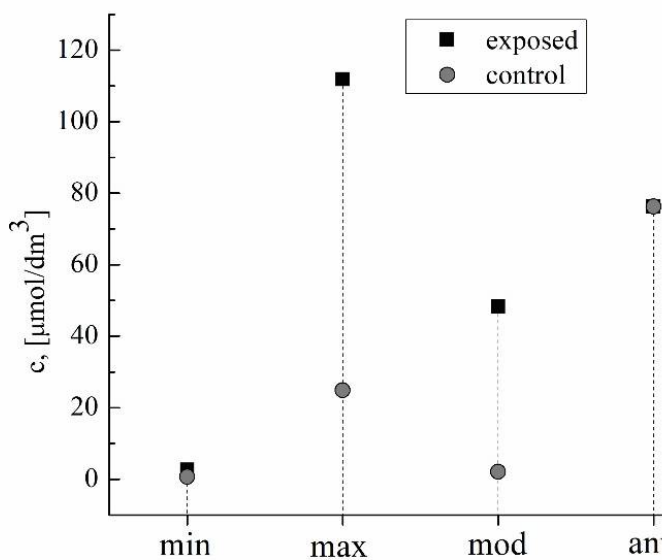

(b)

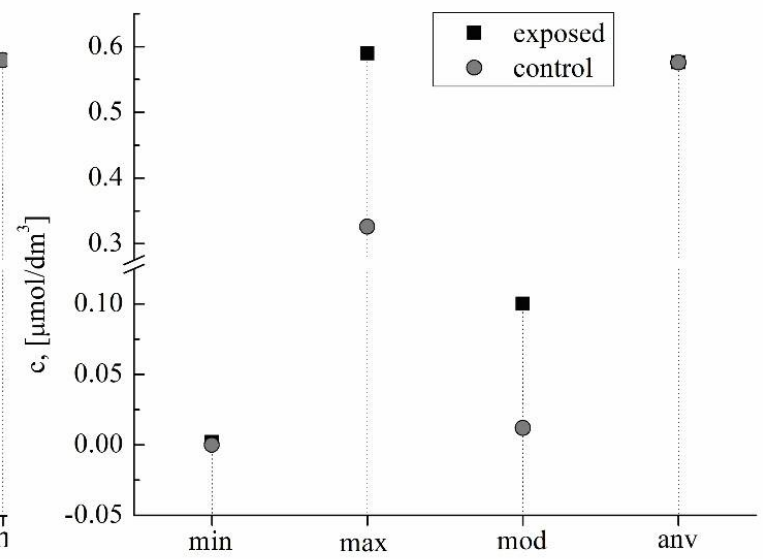

(d)

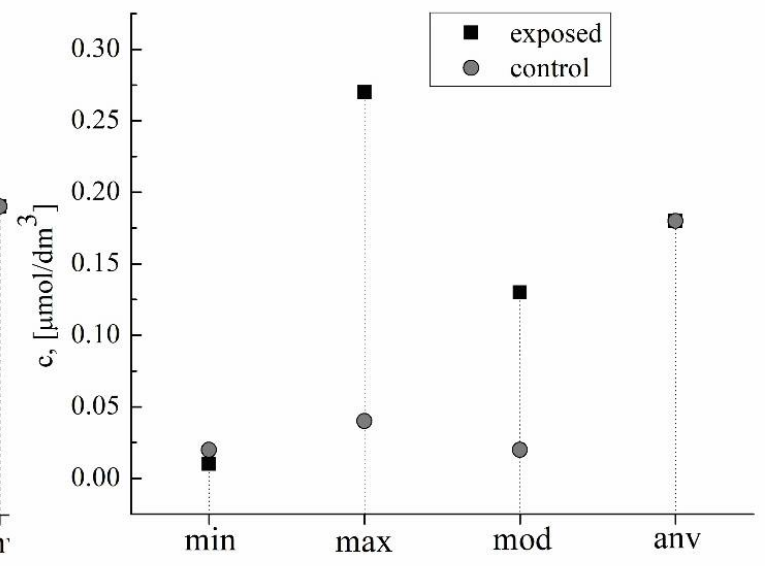

min- minimum value; $\boldsymbol{m a x}$ - maximum value; $\boldsymbol{m o d}$ - most frequent value; $\boldsymbol{a} \boldsymbol{n} \boldsymbol{v}$ - allowed normal value

Figure 2: Some specific values of $\mathrm{Pb}$ in (a) blood and (b) urine; as well as of (c) $\delta$-ALA and (d) CP in the urine for exposed and control groups

An overview of the monitored parameters, such as minimum and maximum values, the mode values, and the allowed normal values for each parameter in exposed and control groups are shown in Figure 2.

The blood lead level was $1.39 \mu \mathrm{M}$ for the exposed group and $0.32 \mu \mathrm{M}$ for the control group of employees (Figure 1). The mode values were $1.43 \mu \mathrm{M}$ for the exposed group and $0.15 \mu \mathrm{M}$ for the control group, while the maximum value in the exposed group was $2.43 \mu \mathrm{M}$, and $1.40 \mu \mathrm{M}$ in the control group (Figure 2a). Experimental data for blood lead levels were within the allowed range for this metal.

The mean value of urine lead level was $0.20 \mu \mathrm{M}$ for the exposed employees, and $0.08 \mu \mathrm{M}$ for the control group (Figure 1). Figure $2 b$ shows that the maximum value for urine lead level for the exposed group $(0.59 \mu \mathrm{M})$ was higher than the allowed value $(0.576 \mu \mathrm{M})$, which makes lead in the urine an important parameter to be considered.
Data from Figures 1 and $2 \mathrm{c}$ show that the values of $\delta$-ALA for the control $(4.90 \mu \mathrm{M})$ and the exposed $(43.7 \mu \mathrm{M})$ group were lower than the allowed values of this parameter in the urine $(76.3 \mu \mathrm{M})$. The mode value of $\delta-A L A$ in the exposed group was $48.3 \mu \mathrm{M}$ (Figure $2 \mathrm{c}$ ), which is slightly higher than the mean value. The maximum value of this parameter determined in the exposed group was $111.9 \mu \mathrm{M}$ (at cca. 80 employees), which is higher than the mean value and the allowed value $(76.3 \mu \mathrm{M})$ of $\delta$-ALA in the urine.

The value of coproporphyrin was $0.03 \mu \mathrm{M}$ for the control group, and $0.12 \mu \mathrm{M}$ for the exposed group (Figure 1). Coproporphyrin concentration from the exposed group was close to the mode value $(0.13 \mu \mathrm{M})$, and both were lower than the allowed value $(0.18 \mu \mathrm{M})$, Figure $2 \mathrm{~d}$. This parameter was characterized by the maximum value $(0.27 \mu \mathrm{M})$ which is higher than the normal mean value and the allowed values. 
(a)

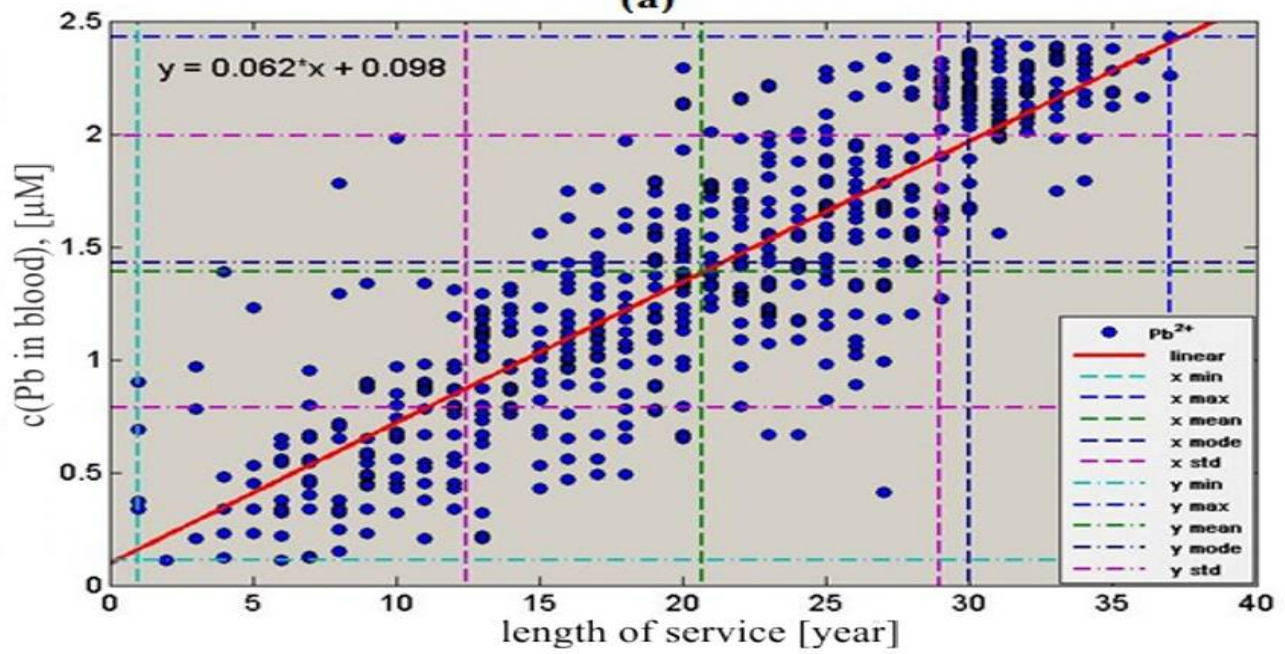

(b)

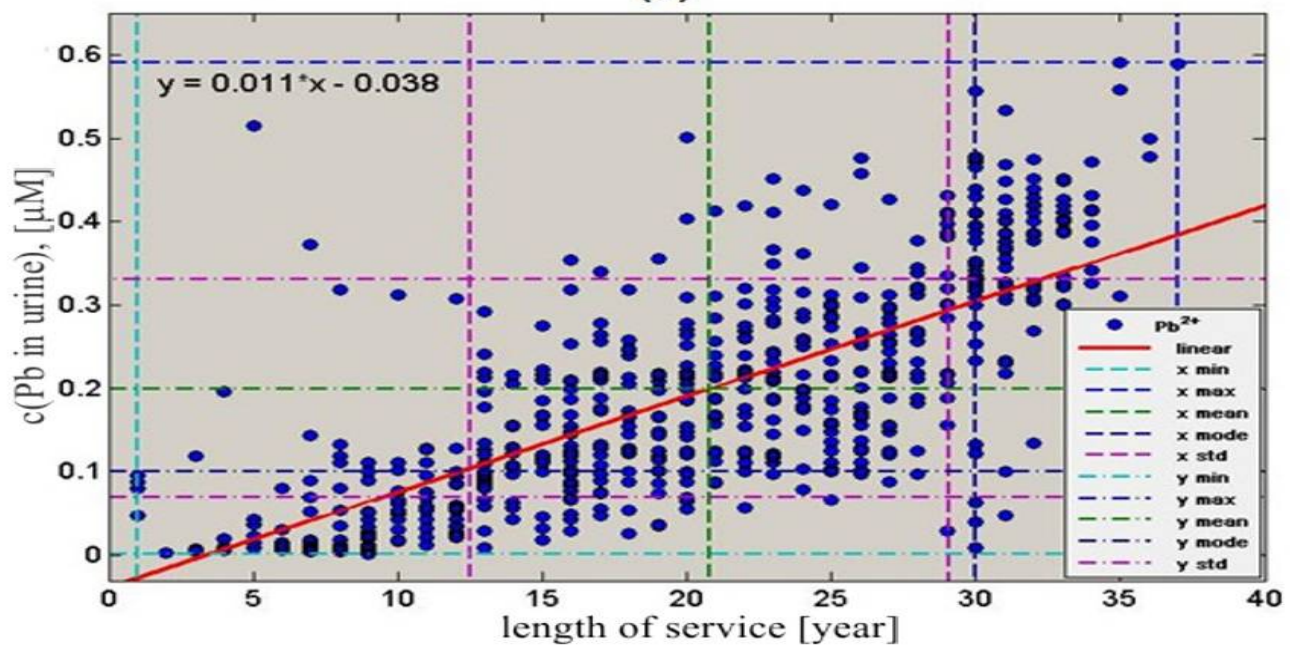

Figure 3: Dependence between the length of exposure and lead levels in (a) blood and (b) urine

The relationship between the influence of the period of lead exposure and values of the monitored parameters in the blood and urine was evaluated using the Pearson's correlation coefficient (Table 2).

Table 2. Correlation of length of exposure with monitored parameters

\begin{tabular}{|c|c|c|c|c|}
\hline & $\begin{array}{c}\mathrm{Pb} \\
\text { (blood) }\end{array}$ & $\begin{array}{c}\mathrm{Pb} \\
\text { (urine) }\end{array}$ & $\begin{array}{l}\text { ס-ALA } \\
\text { (urine) }\end{array}$ & $\begin{array}{c}\mathrm{CP} \\
\text { (urine) }\end{array}$ \\
\hline$r$ & $0.854^{* *}$ & $0.722^{\star *}$ & $0.767^{* *}$ & $0.843^{\star *}$ \\
\hline
\end{tabular}

According to the data in Table $2(r>0.70$ for $\mathrm{Pb}$ and $\delta$-ALA in the urine, as well as $\mathrm{Pb}$ in the blood and $\mathrm{CP}$ in the urine) there is a high positive correlation between the evaluated biological parameters and length of exposure, with statistical significance at $p<0.01$.

The dependence between the length of exposure and the concentration of the measured parameters in the biological material of the exposed group was evaluated using the MATLAB software. Figure 3 shows the dependence between length of exposure and lead levels in the blood (Figure 3a) and urine (Figure $3 b$ ), while in Figure 4 the dependence data for $\delta$-ALA (Figure 4a) and CP (Figure 4b) in the urine are shown. The obtained data show a linear dependence, and considering the higher order polynomial interpolation, have the smallest margin of error within the range observed.

Correlation data concerning the relationship between lead levels in the blood and urine, and values of $\delta$-ALA in the urine are presented in Table 3.

Table 3: Correlation between lead and $\delta$-ALA concentration

\begin{tabular}{c|cc}
\hline & $\mathbf{P b}$ (blood) & $\mathbf{P b}$ (urine) \\
\hline $\boldsymbol{r}$ & $0.766^{\star \star}$ & $0.703^{\star \star}$ \\
\hline $\boldsymbol{r}=$ correlation coefficient; ${ }^{* \star} p<0.01$
\end{tabular}


(a)

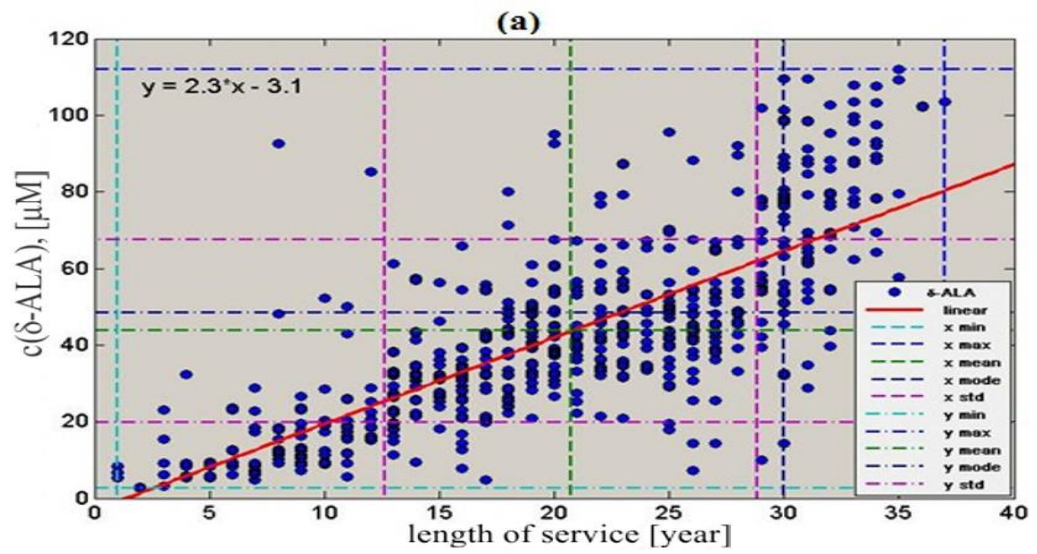

(b)

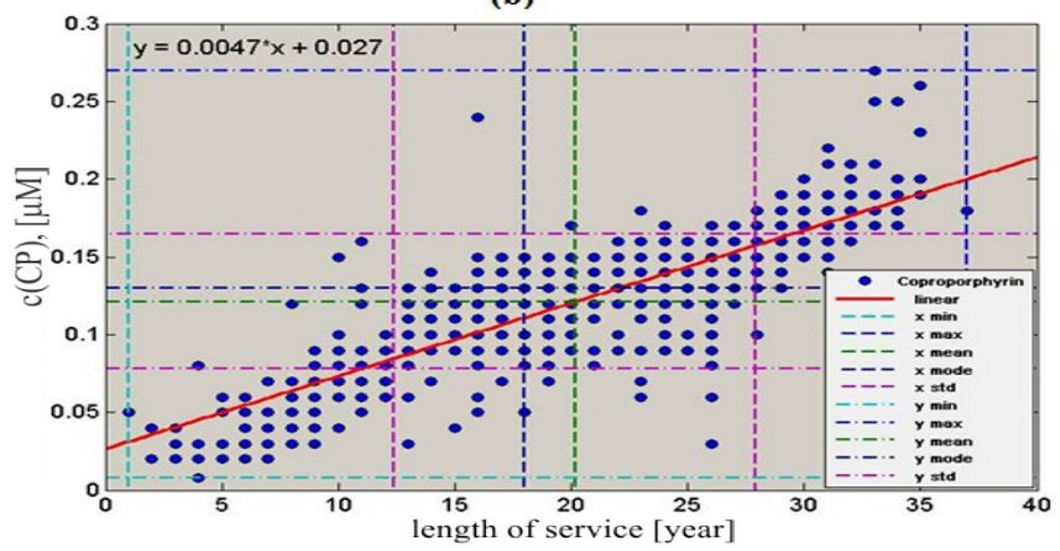

Figure 4: Correlation between length of exposure, and (a) $\delta$-ALA and (b) CP in urine

According to the data (Table 3), there is a statistically significant $(p<0.01)$ positive correlation between lead levels in the blood and urine, as well as $\delta$-ALA concentration in the urine. Therefore, a higher concentration of lead in the blood and urine causes a higher concentration of $\delta$-aminolevulinic acid in the urine (Figure 5).

Correlation data related to the relationship between lead concentration in the blood and urine, and values of $\mathrm{CP}$ in the urine are presented in Table 4.

Table 4: Correlation between lead concentration in the blood and urine, and values of CP in the urine

\begin{tabular}{c|cc}
\hline & Pb (blood) & Pb (urine) \\
\hline $\boldsymbol{r}$ & $0.765^{\star \star}$ & $0.688^{\star \star}$ \\
\hline $\boldsymbol{r}=$ correlation coefficient; ${ }^{\star \star} p<0.01$
\end{tabular}

There is a statistically significant positive correlation between the concentration of lead in the blood and urine, and the concentration of coproporphyrin in the urine of the exposed group (Figure 5). Higher concentrations of lead in the blood and urine cause higher concentrations of coproporphyrin in the blood. The recorded correlation is relatively high and statistically significant at $p<0.01$, which indicates $99 \%$ certainty.

\section{DISCUSSION}

Blood lead level is the most appropriate indicator of real, current, or previous continuous exposure to this toxic metal $[3,4]$. Even with low concentrations in the blood lead has neurotoxic effects, as well as a vasoconstrictive effect; therefore, it can have nephrotoxic effects and influence on the activity of some enzymes and values of blood parameters $[2,16,17]$. Blood lead levels of the exposed and control group are cca. $50 \%$ and cca. $90 \%$ (respectively) lower than the allowed value (Figure 1). The maximum value for the exposed group is cca. $15 \%$ lower, and for the control group is cca. $50 \%$ lower than the allowed value (Figure 2). The difference between the control and the exposed group $(1.07 \mu \mathrm{M})$ is statistically significant at $p<0.05$.

The data obtained in this study for the control and exposed group are higher than the allowed lead values in some industrialized countries (Table 1). According to the literature data, a longer period of exposure to low toxicity levels (< $1.16 \mu \mathrm{M})$ can cause various psychological conditions and learning disabilities in children [6]. Lead concentrations higher than $0.39 \mu \mathrm{M}$ have 

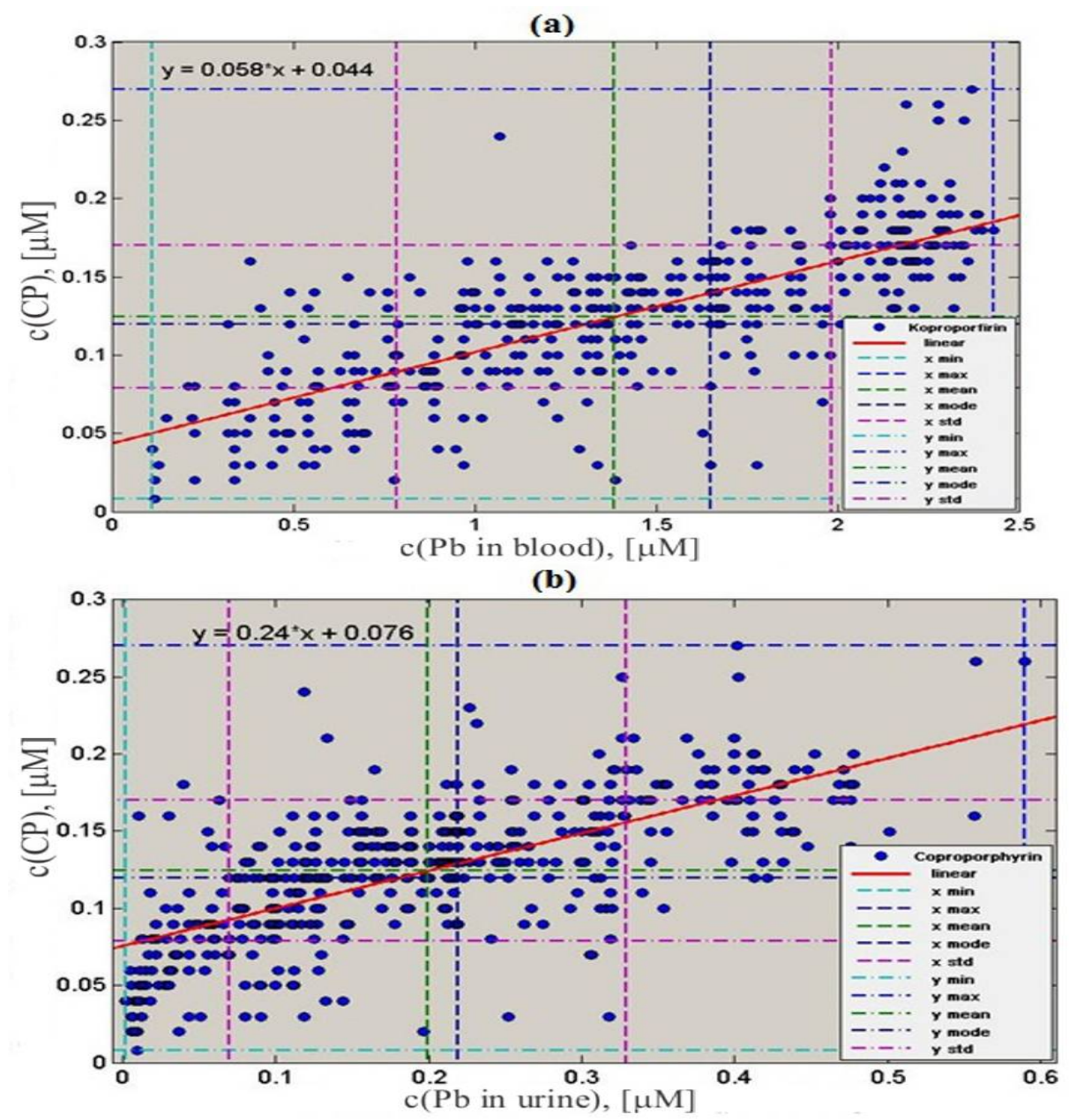

Figure 5: Dependence between CP and lead concentration in the blood (a) and urine (b)

less influence on the cardiovascular system [18], while concentrations lower than $1.93 \mu \mathrm{M}$ have adverse effects on the urinary system [19]. ACDC considers concentrations lower than 1.16 $\mu \mathrm{M}$ as normal, and concentrations of 1.21-2.37 $\mu \mathrm{M}$ as moderate risk concentrations [6]. Based on these facts and the results obtained in this study, the control group of employees belongs to a normal risk category, while the exposed group of employees belongs to a moderate risk category.

The mean values of lead in the urine for the control and the exposed groups are cca. $85 \%$ and cca. $65 \%$ lower than the allowed values for this metal in the urine. However, in some of the employees' urine samples maximum lead levels were found, cca. $2.5 \%$ higher than the allowed value. Also, the obtained results indicate lower lead levels in the urine than in the blood, cca. $85 \%$ lower for the exposed group and cca. $75 \%$ for the control group. The difference between the control and the exposed group $(0.12 \mu \mathrm{M})$ is statistically significant at $p<0.05$. Blood lead levels are a better indicator of exposure than lead concentration in the urine, because the concentration in the urine depends on the specific weight and diuresis [20]. Data from the literature show that exposure to inorganic lead causes increased levels of metals in the urine, around $10 \%$ of the blood intake [21].

Due to the fact that lead inhibits three enzymes in the biosynthesis of heme (ס-ALA, coproporfirinogen oxidase and ferrochelatase) and its effects on the dehydratase of $\delta$-ALA are the greatest, the level of $\delta$-ALA in the urine is increased, and represents the most sensitive indicator of lead toxicity [22].

The obtained values for $\delta$-ALA are lower than the allowed value for this parameter in the urine cca. $40 \%$ for the exposed group, and cca. $90 \%$ for the control group. Coproporphyrin values in the urine show a similar tendency. Maximum values for these two biological indicators which were found in the exposed group are cca. $30 \%$ higher than the allowed values. Differential values between the control and the exposed group for both indicators are statistically significant at $p<0.05$. Analysis of the dependence between lead levels in the blood 
and urine, and the concentration of $\delta$-ALA in the exposed group showed a statistically significant positive correlation at $p<0.01$, which is in accordance with the results of Barbarossa et al [4]. Also, a group of authors found that the increased excretion of $\delta$-ALA begins at blood lead levels from 1.45 to $1.93 \mu \mathrm{M}$, while it is most pronounced at a level between 2.41 and 2.89 $\mu \mathrm{M}$; the increased excretion of coproporphyrin occurs at blood lead levels between 1.69 and $1.93 \mu \mathrm{M}$ [23], similar to the results from our study. The concentration of coproporphyrin in the urine showed high sensitivity $(97.8 \%)$ at the recorded blood lead level of $2.89 \mu \mathrm{M}$. The analysis of the dependence of lead values in the blood and urine, and coproporphyrin concentration in the exposed group showed a statistically significant positive correlation at $p<$ 0.01 .

According to McElvaine et al, the increased levels of coproporphyrin occur when blood lead level is $1.93 \mu \mathrm{M}$ [24], which was confirmed by the results obtained in this research. The obtained results confirmed a high positive correlation between the concentration of lead in the blood and urine, and years of service of the exposed subjects $(r=0.854, p<0.01$, and $r=0.722, p<$ 0.01 , respectively). Lee et al found a high positive correlation between blood lead levels and years of service [25], which complies with the results obtained in the present research.

By analyzing the connection between $\delta$-ALA acid and $C P$, and years of service of exposed subjects in both technological systems, which is again closely related to the connection between lead levels and years of service, a high positive correlation was identified, which indicates the significance of biological markers of lead effect.

\section{CONCLUSION}

The findings of the present study show that the control group of employees belongs to a normal risk category, while the exposed group belongs to a moderate risk category. The difference between the mean values of lead concentrations in the blood and urine in the exposed group and the control group was statistically significant at $p$ $<0.05$. Analysis of the dependence between lead levels in blood and urine, and the concentration of $\delta$-ALA, such as CP in the exposed group, showed a statistically significant positive correlation at $p<0.01$. High positive correlation $(p<0.01)$ between the concentration of lead in the blood and urine, and the years of service of the exposed subjects was also recorded. Additionally, a high positive correlation between $\delta$-ALA acid and CP, and the years of service of the exposed subjects was detected.

\section{DECLARATIONS}

\section{Acknowledgement}

This work was supported by the Ministry of Education, Science and Technological Development of the Republic of Serbia under Grants TR 34008 and OI 176008. The authors would also like to thank Vladimir Figar, MA, for proofreading this paper.

\section{Conflict of interest}

No conflict of interest is associated with this work.

\section{Contribution of authors}

We declare that this work was done by the author(s) named in this article and all the obligations related to claims related to the content of this article will be borne by the authors.

\section{REFERENCES}

1. Nikolić RS, Jovanović JM, Kocić GM, Krstić NS, Glutathione and lipoic acid benefit effects on liver, kidney, brain and pancreatic tissue from $\mathrm{Cd}$-, $\mathrm{Pb}$ - and $\mathrm{Cu}$ - provoked lipid peroxidation monitoring via MDA content among Wistar rats. In: Jackson Campbell, editor. Malondialdehyde (MDA): Structure, Biochemistry and Role in Disease, Edition: Biochemistry Research Trends. Nova Science Publisher; 2015, p. 55-83.

2. Nikolić R, Krstić N, Jovanović J, Kocić G, Cvetković TP, Radosavljević-Stevanović N. Monitoring the toxic effects of $\mathrm{Pb}, \mathrm{Cd}$ and $\mathrm{Cu}$ on hematological parameters of Wistar rats and potential protective role of lipoic acid and glutathione. Toxicol Ind Health 2015; 3: 239-246.

3. BergdahI IA, Skerfving S. Biomonitoring of lead exposure - alternatives blood. J Toxicol Environ Health A 2008; 71: 1235-1243.

4. Barbosa JrF, Tanus-Santos JE, Gerlach RF, Parsons PJ. A critical review of biomarkers used for monitoring human exposure to lead: advantages, limitations, and future needs. Environ Health Perspect 2005; 133: 16691674.

5. Jaffe EK, Bagla S, Michini PA. Reevaluation of a sensitive indicator of early lead exposure: measurement of porphobilinogen synthase in blood. Biol Trace Elem Res 1991; 28: 223-231.

6. Scinicariello F, Murray HE, Moffett DB, Abadin HG, Sexton MJ, Fowler BA. Lead and delta-aminolevulinic acid dehydratase polymorphism: where does it lead? A meta-analysis. Environ Health Persp 2007; 115: 35-41. 
7. Goyer RA. Factors Influencing Metal Toxicity. In: Metal Toxicity, Goyer R, Klaassen $C D$, Curtis $D$ and Waalkes MR (Eds.), Academic Press, San Diego 1995: 31-45.

8. Szymik $E$. The fate of children from Piekary Slaskie with elevated lead concentration in blood. Wiad lek 2002; 55(1-2): 72-80.

9. Sirivarasi J, Kaorjaren S, Wananukul W, Srisomerg $P$. Non-occupational determinants of cadmium and lead in blood and urine among a general population in Thailand. SE Asian J Trop Med 2002; 33: 180-187.

10. Becker K, Kaus S, Krause C, Lepom P, Schulz C, Seiwert $M$, Seifert B. German environmental survey 1998 (GerEs III): environmental pollutants in blood of the German population. Int J Hyg Envir Heal 2002; 205 : 297-308.

11. Apostoli P, Baj A, Bavazzano P, Ganzi A, Neri G, Ronchi A, Soleo L, Di LL, Spinelli P, Valente T, Minoia C. Blood lead reference values: the results of an Italian polycentric study. Sci Total Environ 2002; 287: 1-11.

12. NOHSC-National Occupational Health and Safety Commission. Control of inorganic lead at work: national standard for the control of inorganic lead at work. Australian Government Publishing Service, Canberra, 1994.

13. International Ethical Guidelines for Health-related Research Involving Humans, Prepared by the Council for International Organizations of Medical Sciences (CIOMS) in collaboration with the World Health Organization (WHO). Council for International Organizations of Medical Sciences (CIOMS), Geneva, Switzerland, 2002, ISBN 92-9036-075-5

14. Valcarcel M, Gomez AH, Rublo S, Petidler A. Direct Quantification of Coproporphyrins and Uroporphyrins in Urine by Derivative Synchronous Fluorescence Spectroscopy, Clin Chem 1987; 33(10): 1826-1831.

15. Butnaru E, Mircea C, Butnaru C, Agoroaei L, Proca M, Alexandrescu L, Cotae N. Delta-aminolevulinic acid measurement in people professionally exposed to lead. Rev Med Chir Soc Med Nat lasi. 2004; 108(1): 165-8.
16. Telisman S, Jurasović J, Pizent A, Cvitković P. Blood pressure in relation to biomarkers of lead, cadmium, copper, zinc, and selenium in men without occupational exposure to metals. Environ Res 2001; 87: 57-68.

17. Pizent A, Jurasović J, Telisman S. Blood pressure in relation to dietary calcium intake, alcohol consumption, blood lead, and blood cadmium in female nonsmokers. $J$ Trace Elem Med Bio 2001; 15: 123-130.

18. Lanphear BP, Hornung R, Khoury J, Yolton K, Baghurst $P$, Bellinger DC, Canfield RL, Dietrich KN, Bornschein $R$. et al. Low-level environmental lead exposure and children's intellectual function: an international pooled analysis. Environ Health Persp 2005; 113: 894-899.

19. Kosnett MJ, Wedeen RP, Rothenberg SJ, Hipkins KL, Materna BL, Schwartz BS, Hu $H$, Woolf $A$. Recommendations for medical management of adult lead exposure. Environ Health Persp 2007; 115: 463471.

20. Manton WI, Rothenberg SJ, Manolo M. The lead content of blood serum. Environ Res 2001; 86: 263-273.

21. Bergdahl IA. Skerfving S. Biomonitoring of lead exposure - alternatives blood. J Toxicol Environ Health A 2008; 71: 1235-1243.

22. Kappas A, Sassa S, Galbraith RA. The porphyrias. In: Scriver CR. Beaudet AL. Sly WS. editors. The metabolic and molecular basis of inherited disease, 7th ed., McGraw-Hill Book Company, New York, 1995: p. 21032159.

23. Lee BK. Occupational lead exposure of storage battery workers in Korea. Br J Ind Med 1982; 39: 283-289.

24. McElvaine MD. Orbach HG. Binder S. Blanksma LA. Maes EF. Krieg RM. Evaluation of the erythrocyte protoporphyrin test as a screen for elevated blood lead levels. J Pediatr-US 1991; 119: 548-550.

25. Lee SS, Lee BK, Lee GS, Stewart WF, Simon D, Kelsey $K$, Todd AC, Schwartz BS. Associations of lead biomarkers and delta-aminolevulinic acid dehydratase and vitamin $D$ receptors genotypes with hematopoietic outcomes in Korean lead workers. Scand J Work Env Hea 2001; 27: 402-411. 